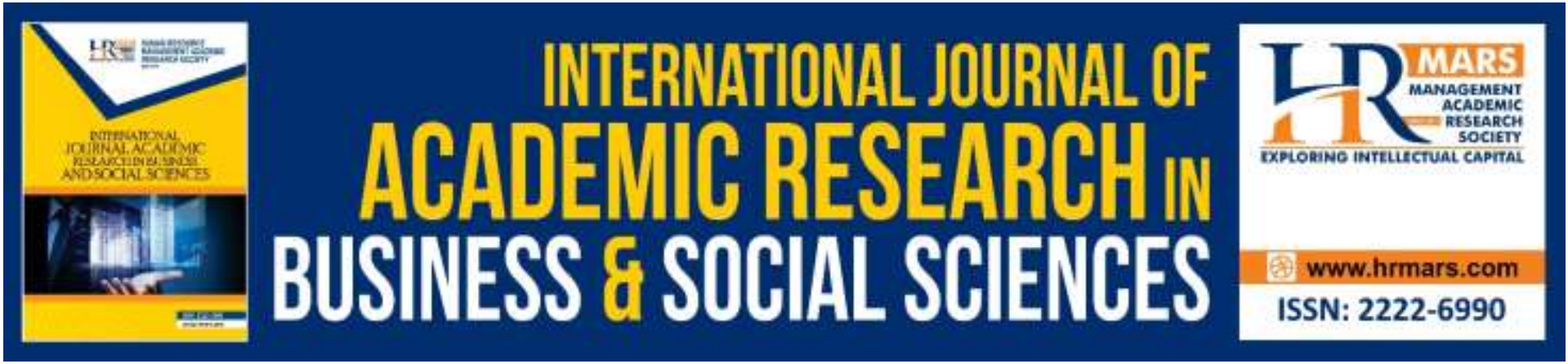

\title{
The Impact of Entrepreneur's Motivation and Competencies: An Exploratory Study of E-Commerce New Venture Creations in Malaysia
}

Ahmad Firdause Md Fadzil, Mohd Rafi Yaacob, Hasimi Sallehudin, Fauzilah Salleh, Mohd Nazri Muhayiddin, Dzulkifli Mukhtar, Rashidah Mohamad Ibrahim

To Link this Article: http://dx.doi.org/10.6007/IJARBSS/v9-i8/6220

DOI: $10.6007 /$ IJARBSS/v9-i8/6220

Received: 07 May 2019, Revised: 11 June 2019, Accepted: 30 July 2019

Published Online: 13 August 2019

In-Text Citation: (Fadzil et al., 2019)

To Cite this Article: Fadzil, A. F. M., Yaacob, M. R., Sallehudin, H., Salleh, F., Muhayiddin, M. N., Mukhtar, D., \& Ibrahim, R. M. (2019). The Impact of Entrepreneur's Motivation and Competencies: An Exploratory Study of E-Commerce New Venture Creations in Malaysia. International Journal of Academic Research in Business and Social Sciences, 9(8), 94-113.

Copyright: (C) 2019 The Author(s)

Published by Human Resource Management Academic Research Society (www.hrmars.com)

This article is published under the Creative Commons Attribution (CC BY 4.0) license. Anyone may reproduce, distribute, translate and create derivative works of this article (for both commercial and non-commercial purposes), subject to full attribution to the original publication and authors. The full terms of this license may be seen

at: http://creativecommons.org/licences/by/4.0/legalcode

Vol. 9, No. 8, 2019, Pg. 94 - 113

http://hrmars.com/index.php/pages/detail/IJARBSS

JOURNAL HOMEPAGE

Full Terms \& Conditions of access and use can be found at

http://hrmars.com/index.php/pages/detail/publication-ethics 


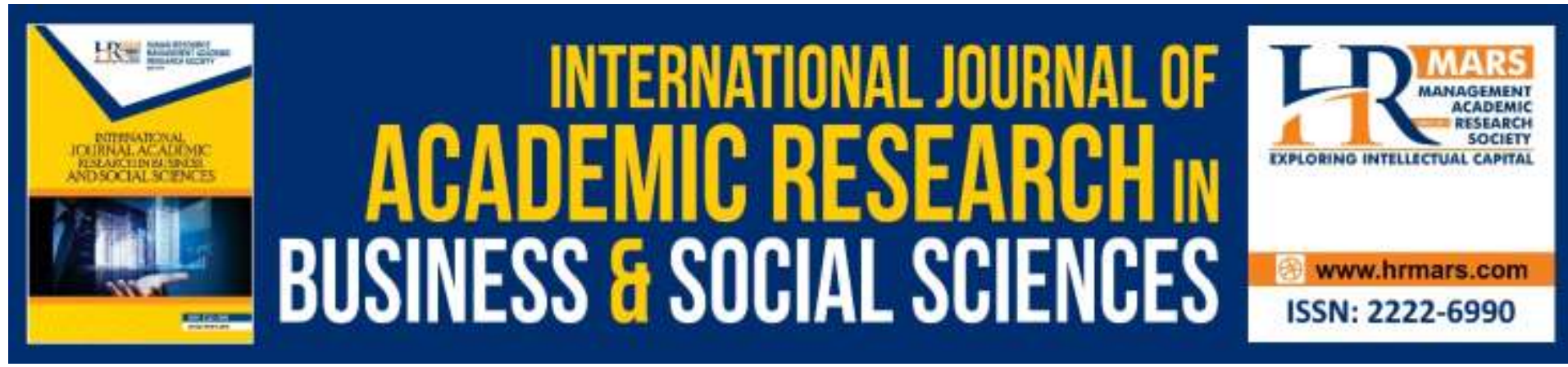

\title{
The Impact of Entrepreneur's Motivation and Competencies: An Exploratory Study of E- Commerce New Venture Creations in Malaysia
}

\author{
Ahmad Firdause Md Fadzil', Mohd Rafi Yaacob², Hasimi \\ Sallehudin ${ }^{3}$, Fauzilah Salleh ${ }^{4}$, Mohd Nazri Muhayiddin ${ }^{5}$, \\ Dzulkifli Mukhtar ${ }^{6}$, Rashidah Mohamad Ibrahim ${ }^{7}$ \\ 1, 4, 7 Universiti Sultan Zainal Abidin, 2, 5, 6 Universiti Malaysia Kelantan, ${ }^{3}$ Universiti \\ Kebangsaan Malaysia. \\ Email: firdause@unisza.edu.my
}

\begin{abstract}
Over the past three decades, studies on entrepreneurship reveal that its main components, particularly for new venture creation processes, have been widely highlighted by researchers. An entrepreneur is regarded as the main actor in entrepreneurship who is responsible for a new ventures creation and it involves motivation and competencies in establishing new ventures. Most previous researchers studying on aspects of entrepreneurial motivation have approached the process of new ventures creation in general, but overlooked e-commerce ventures. Previous studies also paid least focus on entrepreneurial competencies which lead to e-commerce new venture creations. In order to fill the lacunae, the aim of this study is to identify the role of entrepreneurial motivation and competencies that contribute to the creation of e-commerce new ventures in Malaysia. This research used a case study approach in which data was collected by interviewing a total of twelve ecommerce entrepreneurs from May 2013 until December 2014. As entrepreneurs are motivated internally and externally, findings from this study identified two types entrepreneurial motivation which are related to internal motivation; (i) need for achievement and (ii) interest. Need for achievement is triggered by two elements; either by push factors such as personal background, or pull factors - the desire for greater income, which has inspired most entrepreneurs to succeed. The other internal motivation, interest is one of the important elements that cause entrepreneur to initiate start-up e-commerce new ventures di Malaysia. Based on this study, entrepreneurs have high interest in business and in information technology such as computers, internet and others. On the other hand, external motivation as a result of interactions with conducive environment such as customers, family members and industries have increased entrepreneur's motivation that gives impact to business success. Research findings also have found that entrepreneurial competencies in both computer and communication skills largely contribute to the creation of new ventures. These skills are essential as it facilitates entrepreneurs in expediting the creation of new ventures. Therefore, the government plays a role in encouraging entrepreneurial activities in
\end{abstract}


the country where there is a need to encourage entrepreneurs' cognitive ability and improve their entrepreneurial competencies in order to boost economic development of the country through the emergence of new ventures in the future.

Keywords: Entrepreneurship, New Venture Creation, Psychology, Competencies and ECommerce

\section{Introduction}

To date, there are many debatable issues discussed regarding areas within entrepreneurship research. Varied opinions are also identifiable within defining entrepreneurship. Davidsson (2005) observed several definitions of the phenomenon of entrepreneurship by few researchers; as a new entry (Lumpkin \& Dress, 1996), the creation of new enterprise (Low \& MacMillan, 1988), the creation of organizations (Gartner, 1988), a process of creating something different with value (Hisrisch \& Peters, 1989). These definitions, however highlighted more on the creation of new organization based on Gartner's (1988) answer to the question "How does an organization come into existence" which involves a complex process through the interaction of various components. Apart from that, many past studies on entrepreneurship have also focused on entrepreneurs' psychology as it is also an important element in the new venture creation. To name a few, Shane (2003) has explored how individual differences may influence the entrepreneur's decision making. She has further added that individual attributes (i.e. cognition, motivation and personality) may influence entrepreneurs in decisions making at discovering and exploiting entrepreneurial opportunities.

The psychological elements such as entrepreneurial motivation, mainly dominated entrepreneurship studies, besides adding on to existing theory of economic and sociological perspectives. Past studies have proven that motivation has become one of the major factors that cause entrepreneurs in exploiting many business opportunities (Shane, Locke, \& Christopher, 2003). This is supported by Segal, Borgia, and Schoenfeld (2005) where they found that one of the reasons for becoming entrepreneurs is one's high level of motivation to be self-employed. Entrepreneurs are motivated by internally and externally, which are related to; (i) need for achievement and (ii) interest. Furthermore, external motivation as a result of interactions with conducive environment such as customers, family members and industries have increased entrepreneur's motivation that gives impact to ventures success (Fadzil 2019).

Recently, many argued that psychological factor alone is inadequate to establish a new venture creation. One should also be equipped with communication and computer skills in order to become a successful entrepreneur (Fadzil, Yaacob, \& Muhayiddin, 2017). This study has found that entrepreneurs' communication and computer competencies play a significant role in new venture creation amongst e-commerce entrepreneurs in Malaysia. Studies on entrepreneurship, particularly regarding e-commerce new venture creation, remain least investigated. Thus, to fill the gaps, this present study aims to know the impact of an entrepreneur's motivation and competencies towards e-commerce new venture creation in Malaysia. Generally speaking, according to Dheeriya (2009) e-commerce can be described as any venture conducted solely on the internet or the World Wide Web. Unlike the brick-andmortar business, e-commerce business mainly uses the internet and technology-based computer systems. Dheeriya (2009) argued that the conceptual framework concerning online entrepreneurship has yet to formally developed to date compared with regular 
entrepreneurship is often debated by many previous researchers. Gartner (1985) explained that the process of new venture creation is likely to vary according to the type of businesses, either industry or specific entrepreneurs which affect the emergence of new ventures. Therefore, there is a need to investigate how entrepreneurial competencies influence the creation of new venture in e-commerce.

Based on previous studies, entrepreneurship can be explained as a factor that contributes to economic development in a country (Carree \& Thurik, 2005; Wennekers \& Thurik, 1999). The phenomenon of entrepreneurship has an impact on market activity and economic system (Davidsson, 2008) through the creation of wealth or the creation of a something value (Drucker, 1985; Morris, 1998) and has encouraged the creation of an entrepreneurial activity for products and services (Shane, 2003). Although entrepreneurship is not considered as a resource of a country, many scholars agree that entrepreneurs and entrepreneurship are the engine of the economic growth.

In this digital age where ICT and telecommunication advance further, e-commerce and other related businesses are blooming. E-commerce however, gained more popularity as it has many advantages. This is true when the contribution of e-commerce entrepreneurship keeps increasing and at the same time, manages to reap billions of dollars, eroding the traditional business chain. It has indeed become a significant component of the global sales revenue growth firms (Dheeriya, 2009). Moreover, an interview with Mr. Azizan Mohd Findi, the General Secretariat of Planning and Coordination Commission, as reported by Sinar Harian newspaper on July 30, 2013, has clarified that the trade in e-commerce in Malaysia in 2010 until 2011, counting for almost two billion dollars and has increased to three billion dollars in 2012 (Mohd Firdaus Hashim, 2013). Although there are no accurate figures explaining the number of business entities that conducted e-commerce business in Malaysia, the amount of three billion Ringgit, contributed to the country's trade in 2012 has clearly shown that the emergence of new ventures in e-commerce in Malaysia is encouraging.

Since entrepreneurship is the engine of economic growth in a country (Baron \& Shane, 2008; Gartner \& Bellamy, 2009) through the creation of new ventures, job creation and innovation, many researchers are interested in exploring issues of motivation like why an entrepreneur decided to start a new business which is not to others (Townsend, 2010). This could be the main reason for the interest of past studies on understanding psychological reason that influence new venture creation, instead of looking at the entrepreneurial competencies.

\section{Methodology}

Twelve successful entrepreneurs who have been highlighted by the Communication Commission (MCMC) 2013 were purposely selected as samples and interviewed for the present study. The samples were varied, according to their business sector, gender, location as well as historical background of e-commerce business. However, these informants share a few things in common where all of them are categorised as small and micro enterprises (MSE) which has a number of employees not exceeding 30 or total sales not exceeding RM30 million a year. They are also active in e-commerce business, where they run a full-time business and their businesses have been operating between one to six years (start-up duration). The interviews were conducted based on semi-structured questions. Each interview was audiorecorded and transcribed verbatim and the analysis of the interviews produced tentative categories or themes to answer the purpose of study (Merriam, 2009). 
In the early stages of data analysis, the tentative themes were inductively discovered based on the research questions. Once the themes were built, a comparative analysis of the data was made based on categories. There are several steps to analyse the data inductively (category construction), which begins with open coding on a passage in the interview transcripts which aim to answer the research questions (Merriam, 2009). The coding was then grouped under one category which is formally known as axial coding by Corbin and Strauss (2008). There are basically three stages involved in themes development; open coding, axial coding and selective coding. This is in line with what was proposed by Corbin and Strauss (2008) in the Grounded Theory. According to them, tentative themes begin once the researcher starts to analyse the data with open coding; identifying themes by constantly examining the interview transcripts line by line. The themes constructed are important in answering the research questions of the study. After the interview, transcripts are thoroughly reviewed and open coding is then placed under the axial coding; "coding that comes from reflection on interpretation and meaning". In other words, axial coding is derived from several open coding that share similar meanings that construct a particular theme. The last stage involved in this data analysis is selective coding where the researcher selectively codes the main categories that comprise of several axial coding, which supported the construction of the main categories.

\section{Findings}

The interviews identified several elements of motivation, which provided strong support to justify the creation of e-commerce ventures in Malaysia. Motivation is caused by certain factors which influence the entrepreneurs' behaviour. This study has found that increasing entrepreneur's motivation is divided into two factors, namely internal and external stimulus. Internal stimulus is the motivation that appears within the entrepreneurs' selves where they have the desire to succeed and personal interests which influence their behavior to act upon achieving a goal. The external stimulus is the motivation that arises from the external environment which affects their behavior to act entrepreneurially.

\section{a. Need for Achievement}

The first internal stimulus for entrepreneur motivation theme is concerned, namely, the desire to succeed in business in the future. Entrepreneur motivation arises from the desire to achieve success which is driven by pusher factors (such as personal background and attractions namely the desire for lucrative income gained from e-commerce business).

Historical background has been instrumental at triggering entrepreneurs' desire to succeed in achieving a goal in the future. Someone who grows up in a poor family will be more exposed to the entrepreneurial engagement for respective changing lives through business opportunities. The interview reveals that some entrepreneurs have a history of family difficulties before venturing into entrepreneurship. This can be proved a result interviewed with $\mathrm{P} 1, \mathrm{P} 2, \mathrm{P} 5, \mathrm{P} 7, \mathrm{P} 9$, and $\mathrm{P} 12$ with their desire to succeed in the future.

This fact was recognized by P1 who has high desire to change his standard of living by selling products based on kapok pillow. $\mathrm{P} 1$ who is from a poor family in a rural area of Kedah has taken over his family business since the year 2006. Armed with high spirits and ambitions, $\mathrm{P} 1$ has succeeded in changing the competition of the business after running the e-commerce since 2011. In addition, his self-motivation shoots up after seeing the potential of kapok pillows in the region which was the least competitive. P1 has high goals at changing the way 
existing business model to e-commerce where he:

"first try looking at this areas... the way people do business ... will it go forward? selling a pillow with traditional platform? That motivated me to change the current business approach to e-commerce" $(P 1)$

The same situation was experienced by $P 9$, who desired to succeed. He was also from a poor family. Previous experience has motivated P9 to become a successful entrepreneur by running his own business later. P9 rationalized that working with other people does not guarantee future success. He was determined at taking another person's failure to change his standards of living. He was more interested in becoming entrepreneur that allowed him to gain lucrative income. Quotes P9:

"Since a child, I was interested in doing business. My family comes from the poorest background. So I was determined since I was a child to be rich through own business... I don't want to work with someone else because I know it won't change anything. When I retire, I don't want just to have a proton car. I don't want to be insulted, but I have seen it since I was a child. If you want to be rich, do business... I remember the richest person in my village... Doing a start-up patrol station business. ". (P9)

As such, P9's aspiration to become a successful entrepreneur was in line with the trending of e-commerce businesses in 2008 that promises good opportunities. Here is a P9 quote:

"At that time in 2008 ... The trend was using blog shop as the business platform. So, I took that opportunity. I know online as good business. So, I make it. It's not about online business, but it's about good business. I do that. Looks to the new future. "(P9)

The same thing was recognized by $\mathrm{P} 2$, who was not interested in working with others as a result of family motivation that always encouraged her to become successful entrepreneurs. Career as an entrepreneur has become a family pride rather than choosing to work with others which does not change standards of living. Entrepreneurs are able to multiply their earned income and improve their standards of living unlike those working with others:

"It's a matter of family motivation, my dad, even though my father is a farmer but he has a spirit of enthusiasm for our siblings. It's no word to work with people which is our family pride... Greater. Half of the family say working with the government is better than doing business, with business, one is not certain... But for us, government work is just a temporary. I have four male siblings; all four of us resigned as government servants" (P2)

Family background also pushes P10, P12 and P5 to change their future life destiny. All of them realized that it is not easy to change things in life without having the motivation and making the effort to start a business. Despite of their family background, the desire to change the fate of their lives has always been a priority in planning. Here is one quote by P12 to illustrate this situation:

"I was raised in a poor family. It means nothing special with my family, same as others. My father was a lower class worker. So I tried changing my life. I want to feel how happy rich people feel. From there, I become passionate about doing business. From there, I tried my best to grow my business" (P12)

As explained, entrepreneurs are those who have high ambitions to success especially of their businesses. In addition to motivation which is driven by historical family background, the need for achievement is also caused by certain motives achievable through e-commerce business. These motives determine the goals that someone wants to achieve in life either 
financially or otherwise. For the context of this study, entrepreneurs are those who have high goals to achieve success in businesses and they have specific targets. This situation is explained by some statements from interviewing P4, P5, P6, P7, P8 P10 and P11 who are observably have certain goals to be achieved regarding their business success in the future. But the researchers only quoted two passages by P11 and P8 to strengthen the researchers' justification on this issue. The ultimate goal that P11 wants is to be the leader in the product brand. Desiring to have a great following on the built business platform is a good strategy to increase the brand of the product in the Malaysian market in the future:

"The thing that motivates me to become number one, I mean is like my brand, is to be number one amongst the tops, that makes me want to plan. I think that's why I want to be top brands to and I'm famous for it. "(P11)

The same opinion is shared by P8 who has specific goals to achieve in the business despite of family opposition. In addition to success in e-commerce business, P8 also aspires to penetrate the international market by owning a business network to Dubai, New York, and London. This desire pushed P8 to work harder in order achieve the goals:

"The most motivating thing for me is actually the goal that can be achieved.... I want to go international and I want to open a network up to Dubai, New York, and London. So it's a mission ... So I do not stop till I succeed. "(P8)

Self-determination is the basis for entrepreneurs to achieve of the goal. Without a clear goal, it is impossible for entrepreneurs to succeed in business. Entrepreneurs who have a goal will be more open to look for business potential. The ability of entrepreneurs to identify potential business depends on the information received. This fact is acknowledged by P10, who have desires to become a successful entrepreneur through e-commerce business as income generating:

"I see that (success) ... because I'm got the information in the book. I realize about the potential to generate a lot of money, being able to enjoy of doing business, I read not just one book, but many books. All the business books stories. Who are the rich people we see in the world? Most millionaires in world or in Malaysia, all of those are businessmen ... "(P10)

P3 shared the same opinion, pointing out that searching for internet successes has revealed the potential of e-commerce business where there is a lines of stories on business start-up by entrepreneurs from abroad. All of them share common features: they are in the early stages of start-up, operating only at home with low cost expenses before moving to higher reputation in business. What needs to be emphasized is that computer skills, marketing techniques and strategies become good aspiration to other entrepreneurs:

"Because I was searching in the internet ... I read, I did some research in the US, in the UK what all of them did business and went through the same process. Starting business at house, no need much money, free ... But they used internet for marketing... "(P3)

The potential of e-commerce business is indescribable when it enables entrepreneurs to generate money. Entrepreneurs who dare to seize the opportunity to explore potential ecommerce businesses will be more competitive based on business advantages. The advantages of e-commerce are providing excellent income to entrepreneurs. It is acknowledged by P10, explaining the high commitment of living in the cities which encouraged him to start e-commerce business in order to generate income easily as a way to bear the living cost:

"It is able to give a better income. Living in the city is very expensive and we might fail to deal with commitments of surviving here...So how? How can we make sure that we have income 
every month to pay our commitments? So I see that e-commerce is potential and that motivated me to do so. I'm interested in online business; I see the potential of being very easy with the knowledge ... make money via online business"(P10)

Good income generation through e-commerce is due to possibility of dispensing unlimited quantity of products sold to certain locations but also enabling the coverage of larger markets. For entrepreneurs with broader market penetration, it will indirectly increase the quantity of product sales to customers. This fact was acknowledged by P7 and P4, reflecting that unlimited e-commerce business (sales volume) as compared to regular businesses is due to high market penetration rates. P7 explained on this situation:

"Online marketing is unlimited. If you sell a burger a day for at least 100 pieces, tomorrow 150 pieces, after that 120 pieces ... this is an average quantity... but if you sell online, the income is unlimited ... It's fun doing online business... we have no average. unlimited quantity of selling"( $P 7)$

Therefore, in order to generate good income many entrepreneurs have aimed to generate substantial profits in the business by selling products not only locally but also internationally. To generate huge profits in business, entrepreneurs should emphasize marketing aspects by introducing products to customers. Therefore, P1 and P5's initial plan of establishing an e-commerce business is due to the desire of marketing products and generating greater income. E-commerce business enables the generating of higher income as due to its unlimited market expansion. Here are two quote passages by P1:

"Like I said before, start from marketing ... emphasize on marketing. So we introduce our goods, customers are out there "(P1)

"To succeed, we need to sell our goods. So if we do not sell our goods, how can we get profit? The way of marketing... which is the way of our product is marketed (online) ... "(P1)

Marketing trends in e-commerce is the most effective way in business today where entrepreneurs need to pursue opportunities to maintain in growth. Business success is seen more easily based on the assumption that larger market penetration leading to more sales quantities. Thus, e-commerce marketing techniques compliments conventional marketing tools in terms of introducing and attracting customers to buy products in the market. Here is a quote by P2:

"It's about business success, we need go through online platform. This online business is actually one of the latest marketing techniques nowadays, so if you want to be successful today, online business is easier to succeed. It's easy for us to sell our products if we have an online business ... "(P2)

The success of entrepreneurial businesses is often measured based on the quantity of product sales in the market. For entrepreneurs who are want to succeed in business should focus on marketing aspects to introduce products to customers. Generating great income in business depends on the quantities of sold products through market penetration. Thus, entrepreneurs should pursue the opportunity by starting e-commerce business to explore new market opportunities in order to generate more profit. Therefore, P1 is confident to grow the business, and expand the product to global market achieved only through e-commerce business. Here is some quote by $\mathrm{P} 1$ :

"So if we want to expand our market. We can't only depend on existing market. We need to improve ourselves by having a good marketing plan. Emphasize on marketing first. So, that why marketing is important to entrepreneurs "(P1)

"If you do not do online business, the product market spread is lesser. So we need to introduce 
our product. It's important to be marketed. So current situation in this era need everyone uses online to good move "(P1)

The same fact is acknowledged by P12, who saw the opportunity of marketing products through e-commerce business in order to generate more revenues. Entrepreneurs are now heavily dependent on e-commerce businesses if they want to get higher profits as compared to regular businesses. E-commerce business has provided a platform for entrepreneurs to market their products to customers throughout Malaysia. To expand the product market, e-commerce business is the right choice to attract buyers who are far from business locations. Internet provides a link between the entrepreneurs and the customers. Here is an excerpt by P12;

"Like I said, we want to market our brand, our products, we use online. It means if we are not using online, how do we get buyers from all over in Malaysia? From there we can see online is very important. In terms of helping our business. It means we use it online as well. We know about online; we know how buyers use online to buy our goods. We can generate more revenue "(P12)

\section{b. Interest}

The second sub-theme is about the entrepreneur's interest which is great influence on the e-commerce new ventures in Malaysia. Interest is an internal stimulus in entrepreneurial motivation to start-up new ventures apart from the desire to succeed. The difference between interest and need for achievement by entrepreneurs is based on motives. Interest is derived from the tendency or desire for something that fulfills individual needs without having any particular motives while need for achievement is driven by other motives such as to changing of life, the desire to become the rich person and others which is affects the individual behavior. Therefore, a person's interest in something can contribute to the process of e-commerce new ventures in Malaysia.

Findings from this study found that seven out of the twelve interviewed entrepreneurs linked their interest in motivation that contributed to the creation of e-commerce new ventures in Malaysia. The interests highlighted by entrepreneurs are generally divided into two aspects, namely in business and information technology. Both types of interest make an important combination of creating e-commerce ventures which entails entrepreneurs favoring in business and information technology.

Interest in business is an important basis that motivates a person to become an entrepreneur and creating new business. Interest encourages their intentions where individual behavioral at trying something according to the intention even without having a clear motive. Interests are often associated with historical backgrounds where they encourage them to behave in that way. This fact is evidenced by P1, explaining interest is a result of self-disclosure of businesses acquired since the time of helping small-scale family businesses. The same fact is acknowledged by P3 who has a very special interest in business since a child. Having a hard working attitude has been an advantages to start-up new ventures as consistent developed currently. Here are quotes P1 and P3;

"Business knowledge is originally because of an interest ... When you are interest in business it comes too ... Because I was born my mom was already involved in small business ... she was selling a variety of goodies such as cakes"(P1)

"I like doing business since a child. I always think about business matters. I'm workaholic. I work as hard as I could ... So if I doing business, the more money I can get ... So, I do business 
A slightly different situation happened to P11, who began to identify his interest in doing business after studying tourism as a degree as well as in marketing. Knowledge learned in marketing has risen P11's interest in business, and he exploited this interest after graduation:

"So, Alhamdulillah that tourism courses are a lot of marketing study... After that, I know what I'm interested in ... after my graduation. That's time I know my interests to doing business. "(P11)

Interest has turned out to widen additional opportunities for P11 and P8 to always work tirelessly in order to manage business until it succeeds. Without having keen interest, it is impossible for a person to become an entrepreneur and manage a challenging business. Business interest has taught them to be consistent and to be persevere even when they have to face big losses. This fact is explained by P11 and P8 who said:

"I really have interest in the business, but I do not know. Because at the beginning I don't think seriously when doing business... When I give up, I will stop to doing business ... But everything changed when I was involved with hijab stuff... I never want to stop doing business". (P11)

"Both... passion ... deep interest. But some people may not see them as important, but for me, passion and interest have caused me to quickly become despair. My losses were not RM50 or RM100 ... But hundreds of thousands. I stay on making t-shirts and not to do anything else, "(P8)

For $\mathrm{P7}$, interest in the e-commerce business is due to the possibility of making more. The experience of spending a lot of time on online gaming has opened his mindset to do other more beneficial activities like running an e-commerce business. It turned out that as a result of his change of attitude, it has triggered P7's interest in e-commerce and led to success in business. Here's an excerpt by P7:

"One, the main point is in deep interest. We are interested to do online business because it can give good income... So, from there I think we could get easy money from online business... So, the main point is to be interested in business "(P7)

In addition to business interests, entrepreneurs are also well-known to have high interest level in information technology (IT) which is the basis of e-commerce business. A person with an interest in information technology (IT) are more likely to be susceptible to ecommerce business with the assumption that the relationship between them is closely intertwined. Entrepreneurs who are least interested in information technology (IT) are not likely to carry out e-commerce business that is always demanding and requires fully commitment to use computers:

"Interest in IT.... If we are not interested in IT or computers, we can't do online. Better to go offline ... conventional business. There are people like that "(P9)

The same fact is acknowledged by P10 who is keen with computers. The interest was finally converted into some use when he began running an e-commerce business that was capable of generating huge revenue. Here's a quote from P10:

"But I'm interested in computers, I'm interested with the internet... My father was angry with me because I forgot to eat and to do prayers. He disconnected the internet at home... I did not lose hope ... So I went to the cyber cafe, from morning to night "(P10) 


\section{c. External stimulus}

The third sub-theme is about external motivation, which stimulates the entrepreneurs' external motivation. Unlike internal motivation which is driven by the need for achievement and interest, external motivation is triggered by factors that influence decisions and actions. Findings from the interviews show that external factors have influenced entrepreneurs' motivation during their creation of ventures process. Without the support of external motivation, it is difficult for them to boost business spirit. This fact is acknowledged by P12, where customers' response to the products sold motivated him to continue doing business until he is successful now. Continuous flow of customer support has brought P12 to create a creative product design in order to meet their expectations who continuously support new products offered. The presence of customers who exhibit deep interest in the products sold is a sign of business support that P12 decided to move forward without worrying about market demand. Here is what P12 said:

"The main reason is the strong support from my regular customers who are always demanding for new products from Cala Qisya. From there, I was motivated to continue my business"(P12) "When we've created an attractive product and we market it, we've got buyers, so our customers never stop from purchasing. They need to know what is the new product line and this makes them eager and waiting... From there we can proceed with our business. We feed our customers with information on our new items as well as update them with the current trend "(P12)

Customer support for products can be considered as additional criteria that provide external stimulus for entrepreneurs, besides having internal motivation. There are other interviewed entrepreneurs who have seen the current situation as a stimulus that push them to become more motivated in order to overcome the market gap that exists in the business. For example, P2 tried to further the legacy of traditional crafts that was almost extinct as due to the lack of interest among today's generation. Most active entrepreneurs are now unproductive and become less competitive in producing products in the market. Hence, the gap in the market needs to be considered in order to improve the traditional craft industry in line with people's expectations of the younger generation:

"An example (of moral support) come from customers who want us to continue this business because current generation seem to be able to it ... Most are old businessmen, so customers had to wait long time for parang making ...So we tried to solve the gap. We would try to fulfill customers' order within 1-2 months... So we try to reach our target. Every order will be no more than two months ... Customer will then receive the items ordered"(P2)

The situation in traditional craft industry is now very challenging which is currently monopolized by middlemen who in general, control market price. As a result, the monopoly affected the lives of traditional craft entrepreneurs who face difficulty and orders are completed late, unlike the promised date. The middlemen oppression against traditional craft entrepreneurs has motivated $\mathrm{P} 2$ to overcome the gap. A solution to this problem is to change the strategy by using e-commerce in order to demolish the middleman's monopoly and market the products directly by using e-commerce. Here's a quote from P2:

"Kelantan has a lot of artisans ... but all of them are poor... Why? The main reason is the role of middlemen... The middlemen mainly control market price. Customers would contact the middlemen to order the products ... As an entrepreneur, I don't like what is happening, why the middlemen are playing too much in this industry "(P2)

The level of entrepreneurial motivation does not only depend on internal motivation 
but also depends on external motivation where interactions and support system from the nearest family increase productivity. A circle of supportive people can influence motivation and give impact to the entrepreneurs' actions in the business. Gestures such as personal help, advice, encouragement and information dissemination are reasons for entrepreneur to move towards a successful business. This fact is based on situations experienced by P4 and P10, who receive support from their family members when solving problem in business:

"In terms of friends, surrounding people ... or my family, especially - they always push me to change in life and give me money to run the business start-up "(P4)

"But the wife is ... she always motivates me to succeed in business. So the motivation comes back. When it comes back and I will be stronger to face any business challenges... "(P10)

The study also found that most of the samples agreed that their communications skills have significantly contributed to the success of their new venture creation in e-commerce. Communication skills is important for every entrepreneur when building a business, especially when generating sales. An entrepreneur's ability to communicate properly will serve as an advantage in order to attract customers to buy his products. When attracting customers, an entrepreneur should have the basic communication skills like using words properly in emails or social media chat sites. This is because effective communication skills may influence customers' purchasing decisions. For instance, according to $\mathrm{P} 2$, he has good communication skills as compared to his employees when convincing the customers to buy his products:

"Maybe it is the way we interact with the customers. It makes a difference when we are able to explain well. How good we are when we are communicating with our customers..." (P2)

This is to say that the entrepreneurs should use the right choice of words when dealing with the customers. This is to ensure that the customers are always satisfied throughout the business transaction process. Besides, P2 always give adequate respect to his customers regardless of their social background. He is also good at negotiating with the customers, especially in terms of price reduction, product quality and other special requests.

"When we contact our customers via emails, we use proper words. We do not use any short forms. Customers are valuable. We do not know the age of the customers who email us. They might be professionals, like doctors. We could never know. All we know is their names, not their status. Thus, we must use the standard form while communicating with them in order to show our respect."

Sharing similar opinions with P2, P3 also suggested that entrepreneurs need to learn about internet marketing so to attract customers to buy the products. This is because communication skills are also one part of the marketing strategies.

"We need to talk wisely; [we] must have high communication skills to convince the customers, to attract them... We must learn internet marketing. It will not cost anything, only a good time spent" (P3)

She also mentioned that she has the abilities to communicate well with her customers - a skill which not everyone has. Communication skills have made her more approachable to the customers.

"As an entrepreneur, I always improve my communication skills. Entrepreneurs need to be friendly at all time... Very friendly, customers are always right..." (P3)

She always maintains good communication with her customers to ensure that they are satisfied with the services provided. In order to gain the customers' trusts, it is important for her to be able to communicate well, especially when negotiating with the customers about the pricing and product quality. Thus, it is essential for every entrepreneur to know how to 
make his customers feel special, valued and appreciated.

"We cannot be timid... We should not be shy and when we talk to the clients, we want our customers to feel fun shopping at our store. They come here to buy goods... Door gift, that they have to buy (for a wedding)... How can we be sure that they will buy those things here and not next door (other shops)? The key is to have a good communication skill..." (P3)

This pattern of answers is obvious among the samples. According to P8, e-commerce entrepreneurs must have good communication skills in order to interact with customers. A strong relationship between the seller and customers will only be built when there is good communication during the process of business dealings. The best form of communication to have between the seller and customers is less formal and more like friends. However, it is important for the seller to able to communicate accordingly, especially if the customers are from the opposite gender.

"For online business (communication skills), the relationship isn't fixed. The customers come to our store, we greet and entertain them formally...No, it is more to informal type of relationship. We treat them like friends, not customers. We use informal language with them, but still respect them. Address them politely; call them sir." (P8)

Communication skills is not impossible for entrepreneurs to have as it can be learnt. However, to be a good communicator, one should be able to act naturally, instead of pretending. This will convince the customers that the seller is truthful when doing their business and this will indirectly attract the customers to buy the products. Hence, good communication skills can be a strong marketing tool in attracting and retaining the customers. "It is actually very simple, just be our self... The way we talk shows who we are, so do not act wrongly. We need to be friendly when we are dealing with our customers..." (P8)

Another factor that contributes to a successful new venture creation by e-commerce entrepreneurs is having computer skills. According to P2, he has the competencies to use computer due to his past working experience in a factory that required him to deal with MS DOS computer operating system, which later has tremendously helped him in starting up his online business.

"Because during my previous work in a factory, we have always used the computer software even without the internet access... we started to use the computers since MS DOS time, we know that already..." (P2)

He actually started the new venture in e-commerce in $2008 / 2009$, which took him nearly four years to establish a brick-and-mortar store after recognizing the business opportunities, even at that time when internet has started to boom. Computer skills therefore serve as an advantage to many entrepreneurs in Malaysia in building their businesses. Those entrepreneurs who have the ability to use computers well are usually more recognized in their business, unlike those without.

"I realised the opportunity since I am used to working with computers since the mono chrome operating system era. So I was one step ahead from other people. I used the computers when others knew nothing about it..." (P2)

P8 thoroughly explained on the importance of having basic computer skills when starting-up new venture creation in e-commerce. As a matter of fact, entrepreneurs who start their business using Facebook as the main platform usually need to create a fan page as a medium to interact with the customers. Thus, being computer literate will somehow assist those entrepreneurs in setting up the Facebook medium in reaching their target customers. 
"In online business, we usually need a skill to create a fan page (Facebook), where we need to go through a "trial and error" process to get it done. In doing business online, we really need a skill on how to close a sale. In other words, how to keep our customers coming back for more. That is the real challenge..." (P8)

\section{Discussion}

Based on this study, it is clear that motivation and competencies of entrepreneurs have a great influence in the process of e-commerce new venture creation in Malaysia. The need for achievement or having the desire to success is a motivational element that affects the process of e-commerce new venture creation in Malaysia. High level of motivation depends on certain stimulus that drives entrepreneurs to achieve success. This study has found that there are two main elements of the need for achievement or desire to success that stimulate entrepreneurial motivation to the creation of new venture. These two elements are driven by push factors (such as personal background) and pull factors, where the desire for greatest income has stimulated entrepreneurs to succeed.

The personal background of entrepreneurs who were born from poor families plays a role for creating start-up e-commerce businesses. Raised in a poor family has given the motivation to entrepreneurs to change their lives and to become more successful in the future. Better life is seen only through exploiting business opportunities as opposed to working with others. Income earned through business is unlimited as compared to working with people, which is considered as static and does not rise significantly. Therefore, in order to change their lives, they must grab the opportunity to start e-commerce venture that promises unlimited income. The second factor is the desire to earn high income from their involvement in the business. E-commerce provides entrepreneurs with a lot of advantages, especially the marketing aspects of products that are said to be more widely distributed around the world. Entrepreneurs who have the ambition to succeed in business need to exploit the opportunity to start-up an e-commerce ventures that promises a more excess product in the market. Large market penetration will affect the quantity of product sales and generate higher income.

Researchers found that interest is one of the important elements that leads entrepreneur action to start e-commerce new ventures. Interest has influenced decision and action according to a certain tendency. Based on the context of this study, sampled entrepreneurs established e-commerce new ventures due to having high interest in business based on background historical factors, motives and so on. In addition, they have an interest in information technology such as computers, the internet and others related factors are influences to start the new ventures.

The external motivation was one of the elements that influenced the entrepreneurial motivation and action during the start-up of the new ventures. High external motivation as a result of interacting with the surroundings will give confidence to the entrepreneurs in their decision making. The results of interacting with customers, family members and industries have increased their motivation that can ensure the success of entrepreneurs' businesses in the future as opposed to those who are with a negative surrounding.

Entrepreneurial skills are highly dependent on two important elements - their past experiences using computers as well as their personal communication skills that greatly influence their personal judgment and decision to start a new venture creation. The findings of this study have clearly demonstrated that entrepreneurial competencies are extremely 
related with the entrepreneurs' personal communication and computer skills, which is an advantage to them when starting a new venture creation in e-commerce. Computer is the main tool in e-commerce business which requires entrepreneurs to have special skills on how to explore the internet. These skills are important for creating e-commerce platform (i.e. such blogs, Facebook, website) and marketing during the start-up process. Besides that, personal communication is also another key factor that determines the success of a new venture creation in e-commerce. This is true as entrepreneurs need to have certain skills while dealing with their customers. They should be creative in choosing the right words while communicating with their customers in order to attract their positive decision, especially when buying the products. The framework of entrepreneurial motivation and competencies perspective which is highly important for early new venture creation in e-commerce is shown in Figure 1:

Figure 1: Entrepreneur's motivation and competencies that contributes to the e-commerce new ventures in Malaysia

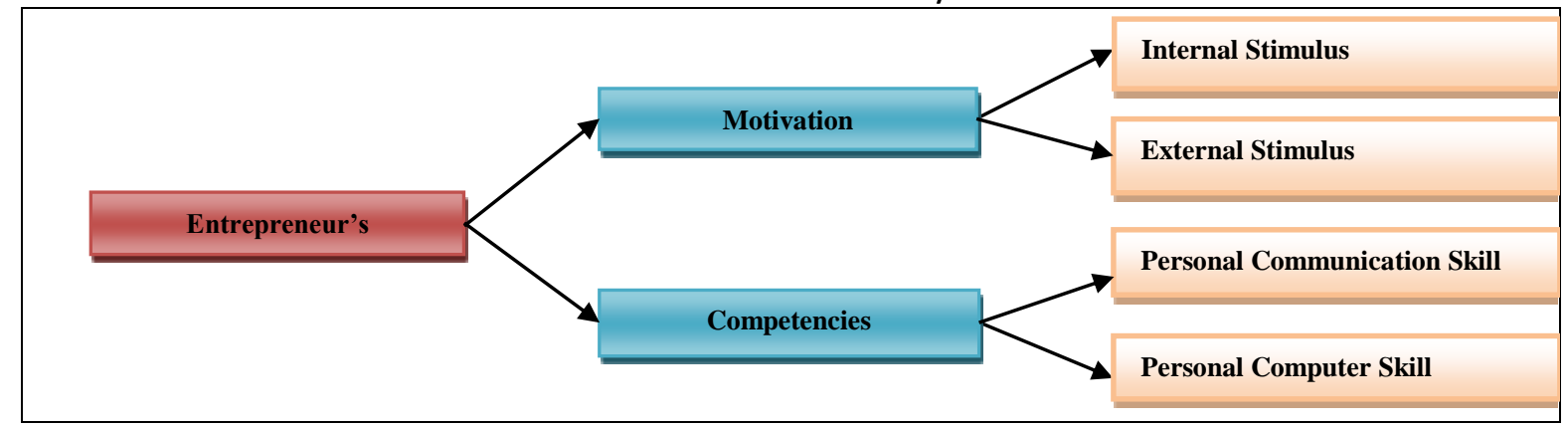

Based on the Figure 1, it shows the roles of motivation perspective which emerge from two main factors that are related to new venture creation in e-commerce in Malaysia. The first main factor related to internal stimulus which contains two essential elements; (i) need for achievement and (ii) interest. Someone who grew up in a poorest family will be more exposed to the entrepreneurship engagement in respective changing lives through business opportunities. Previous experience has motivated them to become successful entrepreneurs when starting-up their own businesses. Some entrepreneurs argue that working with others ensures no future guarantees of changing their lives. In other words, they are more interested at becoming entrepreneurs which allows them to receive higher income quickly. Next is the desire to receive substantial income from their involvement in the business. E-commerce provides a platform that comes with a lot of advantages for entrepreneurs, especially regarding the product marketing aspects where items can be widely distributed around the world. Entrepreneurs who have the desire to succeed in business need to grab the opportunity to start-up an e-commerce venture that promises a broad product marketability. Therefore, larger market penetration will increase the number of sales in order to generate profitable income. Entrepreneurs' interest is also a great influence on the e-commerce new ventures in Malaysia. Interest is an internal stimulus in entrepreneurial motivation to startup new ventures apart from the desire to succeed. The interests emphasized by sampled entrepreneurs are generally divided into two factors namely in business and information technology. Both types of interest make an important combination to e-commerce ventures which entails entrepreneurs favoring in business and information technology. 
Next is external motivation, which stimulates the motivation of entrepreneurs by external factors. Based on this study, external motivation is driven by three essential elements which are family, customer support and situational factors that cause entrepreneurs to become successful in business. Surrounding people who are always giving full support can influence the entrepreneurs' motivation and action in the business. With personal support, advice, inspiration and information, entrepreneurs are likely to become successful in the business. Continuous customer support for existing products can also be considered as additional aspect that provides external stimulus for entrepreneurs to produce a variety of product design in the future. At the same time, the situation in the industry is challenging where market is often monopolized by middlemen who control market prices. The monopoly affects traditional craft entrepreneurs who are continuously oppressed by the middlemen. The solution to overcome this gap is to transform the strategy using e-commerce to market the product and break any form of ties with the middleman.

Figure 1 also displayed that entrepreneurs' competencies which emerge from two main factors that are related to a successful Malaysian new venture creation in e-commerce. The first factor is related to the entrepreneur's communication or personal skills on how to communicate with customers during the dealing process. The second factor refers to entrepreneur's computer skills, especially on working with computers when starting-up new platform, doing online marketing as well as exploring new things.

Personal communication skills play a very important role in the e-commerce new ventures in Malaysia. Having good communication skills gives entrepreneurs an advantage in attracting the customers to purchase their products. A close relationship between the seller and customers will be built based on a good communication where the customers put their trusts on the seller. There is no doubt that entrepreneurs need skills and techniques while dealing with their customers, especially when they have to explain over choices of their products. These special skills in the e-commerce business is however different from those in the brick-and-mortar businesses because they do not involve direct communication. Ecommerce deals more with the non-verbal communication, where most of the time, communication occurs online (via emails, social chat rooms, and newsletters). It is therefore important for entrepreneurs to be able to write properly and rhetorically in order to keep the customers happy and satisfied. This is because an effective piece of writing will surely gain customers' trust and bring large profits in return.

In addition, entrepreneurs' computer skills is also one of the significant factors that contribute to the success of new venture creation amongst e-commerce entrepreneurs in Malaysia. Their past working experience using the computers has significantly helped them in setting up the business. Moreover, their knowledge in computers has also strengthened their skills in exploring the internet to create new platforms such as blogs, websites and social media in expanding their business. Entrepreneurs with basic computer skills are usually one step ahead from the others as they are more advanced in dealing with this technological force.

\section{Limitation of Study}

This study has been conducted by interview-based on purposive sampling and snowball approach among twelve of e-commerce entrepreneurs, as identified by MCMC 2012. This is as the limitation of the study since the selection of the small sample. Selection of small sample sizes based on case studies will tend to make this study inappropriate to be adapted to 
different locations and samples. Davidsson (2008, pp. 54-56) argues that studies of the entrepreneurial process have several challenges that have limited information available. Entrepreneurship research requires a longitudinal study that involves a long process of data collection, starting at the idea generation until the ventures established. While the time taken by an entrepreneur to start-up a new venture also varies. Therefore, this study used data collection methods based only on cross-sectional after the establishment of new ventures without researchers attached through the process during the early stages of start-up. According to Bryman and Bell (2011), the issue of "generalization" is less important in qualitative research as it focuses more on in-depth analysis. Therefore, this study does not represent the entire of e-commerce entrepreneurs' population in Malaysia but is only exploratory study to find out how this phenomenon occurs. Thus, this study emphasizes in more detail the meaning given in the context of the interviews.

\section{Conclusion}

In conclusion, the entrepreneurial motivation is related to internal stimulus which is contain two essential elements; (i) need for achievement and (ii) interest. Need for achievement are led by two elements; driven by push factors (such as personal background) and pull factors, the desire for greatest income has stimulated entrepreneurs to succeed. The next element in internal stimulus is interest - one of the important elements that leads entrepreneurs' action to start-up e-commerce new ventures di Malaysia. Based on the context of this study, entrepreneurs' start-up an e-commerce new venture is due to having high interest in business and in information technology such as computers, the internet and others. The external motivation is one of the elements that influences the entrepreneurial motivation and action during the start-up of the new ventures. High external motivation as a result of interaction with the conducive environment such as customers, family members and industries have increased the entrepreneurs' motivation, driving forth to the business success in the future as opposed to those who are with a negative environment.

Good communication skills will greatly influence the customers' trust and confidence before making any decision to buy the products. The nature of the e-commerce business requires entrepreneurs to realize the importance of effective communication through indirect approaches. Business situational environment requires e-commerce entrepreneurs to focus more on how to attract potential customers at different locations via online platforms like blogs, website or social chat rooms. If entrepreneurs fail to communicate with the customers properly, the business start-up will struggle with sales and management. This is due to the lack of trust gained from the customers. Moreover, entrepreneurs' computer skill is also one of the main tools in e-commerce businesses. It is indeed a must for every entrepreneur to have the ability to use computers, especially on how to set up and maintain the blogs, websites and other social media as it is important during the whole process of e-commerce business start-up.

\section{References}

Fadzil, A. F. M., Yaacob, M. R., \& Muhayiddin, M. N. (2017). The Roles of Competencies in the New Venture Creation among E-Commerce Entrepreneurs in Malaysia. International of Business and Management Invention, 6(3), 25-31. 2019

Fadzil, A. F. M. U. J. H., Yaacob, M. R., Sallehudin, H., Muhayiddin, M. N., Mukhtar, D., Salleh, F., Ibrahim, R. M. (2019). Entrepreneurial Psychology and Competencies: Some 
Perspectives from E-Commerce Entrepreneurs in Malaysia. Journal of Entrepreneurship, Business and Economics, 7(2), 31-79.

Baron, R. A., Shane, S. (2008). Entrepreneurship: A process Perspective Canada: Southwestern Thomson.

Carree, M. A., \& Thurik, A. R. (2005). The impact of entrepreneurship on economic growth Handbook of entrepreneurship research (pp. 437-471): Springer.

Corbin, J., \& Strauss, A. (2008). Basics of qualitative research: Techniques and procedures for developing grounded theory (3th ed.). California, USA: Sage Publications, Inc.

David, M., Townsend, L. W. B., Jonathan, D. A. (2010). To start or not to start: Outcome and ability expectations in decision to start a new ventures Journal of Business Venturing, 25, 192-202.

Davidsson, P. (2005). Researching entrepreneurship (Vol. 5): Springer.

Davidsson, P. (2008). The entrepreneurship research challenge. Cheltenham, UK: Edward Elgar Publishing.

Dheeriya, P. L. (2009). A Conceptual Framework for Describing Online Entrepreneurship. Journal of Small Business \& Entrepreneurship, 22(3), 275-283.

Drucker, P. F. (1985). Innovation and Entrepreneurship: Practice and Principle. New York: Happer and Row.

Gartner, W. B. (1985). A Conceptual Framework for Describing the Phenomenon of New Venture Creation. Academy of Management Review, 10(4), 696-706.

Gartner, W. B. (1988). Who is an Entreprenuer?" is the Wrong Question. American journal of small business, 13, 11-32.

Gartner, W. B., \& Bellamy, M. G. (2009). Creating the Enterprise (1st ed.). Canada: Thomson South-Western.

Merriam, S. B. (2009). Qualitative research: A guide to design and implementation (2nd ed.). San Francisco, CA: John Wiley \& Sons.

Hashim, F. M. (2013). SKMM bantu usahawan mikro, Sinar Harian Malaysia, p. 47.

Morris, M. H. (1998). Entrepreneurial intensity: Sustainable advantages for individuals, organizations, and societies: Praeger Pub Text.

Segal, G., Borgia, D., \& Schoenfeld, J. (2005). The motivation to become an entrepreneur. International Journal of Entrepreneurial Behaviour \& Research, 11(1), 42-57.

Shane, S. (2003). A general theory of entrepreneurship: The individual-opportunity nexus. Cheltenham, UK and Northampton: Edward Elgar Pub.

Shane, S., Locke, E. A., \& Christopher. (2003). Entrepreneurial Motivation. Human Resource Management Review, 13, 257-279.

Wennekers, S., \& Thurik, R. (1999). Linking entrepreneurship and economic growth. Small Business Economics, 13(1), 27-56. 